\title{
Serviceability Assessment of Water Supply \& Its Infrastructure and Associated Challenges for providing Safe Drinking Water in Ethiopia-Gimbi Town
}

\author{
Desalegn Fekadu Etefa, PhD Candidate \\ Ambo University: College of Business and Economics, Department of Cooperatives
}

\begin{abstract}
The development of infrastructure is fundamental to economic growth and development of countries. The objective of this study was to assess the serviceability of water supply \& its infrastructure and associated challenges for providing safe drinking water in Ethiopia-Gimbi town. The research design was descriptive type and the related data was both primary and secondary sources. Primary data was obtained from sample of 219 households, 7 officials and professionals of water office. Samples were drawn, using simple random from the sample frame. Moreover, the water supply infrastructure were observed and photographed and included. Analyses were done by using SPSS and presented by percentage, tables, and charts. The study has confirmed that Gimbi town is facing water supply service problem. The survey result showed that the water produced only covers $30.39 \%$ of the demand. Even if private meter connection is taken as best standards of water supply, the connection for residential consumer is only $22.57 \%$. Furthermore, all areas could not get equal and proportional service. As a result, they are exposed to unprotected sources. The cumulative effect of the existing situations decreased the daily average consumption of pipe water to 6.08 liters per person per day. The study also identified population growth, inadequate source, frequent interruption, unaccounted-for water $(41.25 \%)$, lack of sufficient funding and capacity, lack of standby diesel generator and limited stakeholders' participation as challenges. The paper recommends interventions to overcome water scarcity. These include: exploring additional source, redesigning distribution system, encouraging capacity building for staffs, having standby diesel generator, carrying out appropriate operation and maintenance, introducing rainwater harvesting program, launching appropriate water infrastructural assets management, using water reservoir, promoting stakeholders' participation to improve the problems.
\end{abstract}

Keywords: Accessibility; Affordability; Adequate Water Supply; Infrastructure; Interruption; Meter Connection; Pipe Water; Safe Drinking Water; Unaccounted-for Water.

DOI: $10.7176 / \mathrm{DCS} / 11-5-02$

Publication date:May $31^{\text {st }} 2021$

\subsection{Introduction}

The development of infrastructure is a fundamental precursor to economic growth and development. Most developing countries with infrastructural deficit can hardly create a reliable road map to national development. Of the basic infrastructure, water infrastructure is the most necessary one, which is a prerequisite to the socioeconomic and environmental development of a country. Water is a precious natural resource, vital for life, development and for the environment. It is one of the relatively few items that people take into their bodies each day in order to stay alive. It can be an instrument for economic survival and growth, and also for poverty alleviation. However, when inadequate in quality and quantity, it can rather serve as a limiting factor, resulting in poor health and low productivity, food insecurity, and constrained economic development (UN, 2004). Hence, effective and efficient provision of sufficient potable water supply is one of the basic services, which highly affects the economic progress and the health of the world's people (Le Gouais \& Wach, 2013). As a result of this, its availability, accessibility and affordability for the entire population are of enormous importance.

In spite of this fact, there is a decline in quality and quantity of water resources. According to Hoebink et al. (1998) even if water covers over $70 \%$ of the earth's surface, only the limited quantity is fresh water. This shows that all potential water sources cannot be used for domestic purposes. Consequently, many countries are suffering from shortage of potable water, where the case is aggravated more in less developed countries. According to Aid W. (2006), there are 1.1 billion people across the world that did not get access to safe drinking water.

In addition to the inadequacy of water supply, the means of delivering this basic need of human being is a challenging issue in towns and cities particularly in the developing countries. This is because towns and cities of developing countries receive millions of new inhabitants each year without having the necessary infrastructure facilities. To clarify the issue, Bissoon (2011) stated that investment in infrastructure is part of the unfinished agenda of development in the towns of developing countries. This hinders provision of adequate supply of potable water.

Because of the increasing demand, one in every five people in developing world does not have access to 
safe drinking water and Sub-Saharan Africa (SSA) has the lowest water supply compared to any region in the world (Devarajan \& Reinikka, 2003).

According to the data provided by UNICEF and WHO (2000), only $62 \%$ of the African population has access to improved water supply. Private connections for water in urban SSA remain very low, with only 2-7 connections per 100 people. In addition to these facts, one of the main problems in water supply provision in cities particularly in Africa is the inability of municipal governments to deliver and maintain the water supply infrastructure services for their growing population (Zetland \& Gasson, 2013).

Ethiopia, as one of the developing countries, is not an exceptional case; experiencing the fast growth of urbanization and rapid population growth. The Ministry of Urban Works and Development (MUWD) (2006) report shows that the population of urban areas is rapidly increasing. Consequently, the numbers of locations classified as township in Ethiopia are currently increasing and all requiring basic urban services and infrastructure. But, the water supply sector in Ethiopia is characterized by service deficiency of physical infrastructure as well as by inadequate management capacity to handle policy and regulatory issues (Assefa, 2006). The problem is more serious in small towns that fail to serve utilities including urban water supply properly. This is because remote areas do not have enough trained personal in management, revenue collection, and budgeting and service delivery skills.

According to the recent estimate, the town's population is above 100,000 . The town has mean annual temperature between $18^{\circ} \mathrm{c}$ and $20^{\circ} \mathrm{c}$, while the annual average rainfall is between 1,600 and $2,277 \mathrm{~mm}$, concerning its soil type, most areas in the town have a red clay soil covered with moderately sediment rocks. The town has rugged topography. Urban infrastructure and services, which are important for the socio-economic development, are not adequate in the town, which does not match with the rapid population growth and spatial expansion.

Gimbi town like other developing country's towns has inadequate water supply infrastructure and service delivery. Thus, the study investigates the existing conditions of water supply infrastructure and service delivery in Gimbi town, its distribution systems, causes for the inadequate supply of water, its impact on the socioeconomic development of residents, challenges associated to this and measures to be taken to solve the problem of the town.

\subsection{Literature Review}

Water - a valuable endowment of nature is to enormous degree mismanaged resource globally. The provision of adequate potable water supply in both developed and developing countries is essential for life (UN-Habitat, 1996). This implies that the availability or scarcity of water supply influence development and economic growth of the city and health of citizens. Despite the immense investments and extensive progress made in the water supply sector everywhere throughout the world, giving safe water to the un-served and under-served has been the challenging task faced by the most developing countries. Specifically, many urban centers around the world are facing serious problem of water supply. This is because; all the potential water sources available throughout the world cannot be used for domestic purposes. Besides, there is high rate of water losses from the distribution systems and poor distribution efficiency through city networks. These are contributing factors for the decline of water resources (Habitat UN, 2006). Many studies revealed that unaccounted-for water (UfW) in cities of developing countries is at levels of between 40-60\% of water supplied (Arlosoroff, 1999; Yamamura et al., 2003). This condition created serious water shortage, which limits the availability of water to household domestic consumption.

With this regard, Ladele \& Tackie-Ofosu (2013), talked about various shortcomings, for example, low quality of water services, absence of maintainability of built foundation, challenges for focusing on poor people and deficient internal information systems that keep undermining procedures for poverty eradication. Higher rate of population growth and urbanization, which does not match with the level of infrastructural development are also factors contributing to the limited access to safe drinking water in developing countries. As a result, water supply and service delivery systems in these areas are unable to meet the existing demands and are not available to everyone where the poor is the first victim to be affected by the problem. So, providing satisfactory water supply to the rapidly growing population is becoming a challenging issue to the urban managers. Besides the above facts, one of the main problems in water supply provision in cities particularly in developing countries is the inability of municipal governments to deliver and maintain the water supply infrastructure services for their growing population (Le Gouais \& Wach, 2013). The problem is more prominent in small town's municipalities including Ethiopia that fail to provide urban water supply properly. This is because they do not have enough trained personal in management, revenue collection, technicians in operation and maintenance (O\&M), budgeting and service delivery skills. They are unable to raise sufficient revenue, and many fail to meet even their O\&M costs from the income generated. Consequently, they are not in a position to expand water supply and service projects, to investigate optional water sources, to have enough reservoirs, and reducing water loss at all levels of the distribution systems. Therefore, the urban water supply to function effectively, it needs to be 
supported by appropriate infrastructure in good working condition. Protecting the infrastructure used to treat and transport water (including sources, treatment plants, and distribution systems) is an important step in ensuring the safety of drinking water. However, in most cities worldwide, there have been years of neglected maintenance to water storage, treatment, and distribution systems (Khatri \& Vairavamoorthy, 2007).

Due to all these problems, various organizations for instance Water, S., \& World Health Organization (2004) suggested that new standards for the provision of country water supply should be adopted which include water supply as a service that is monitored and supported by the government and necessities based allocation of activities at community level.

Hence, it is quite indispensable to design the means of providing the basic needs of community through the development of physical infrastructure in general and the provisions of urban water supply in particular through effective organization and management capacity.

\subsection{Study Objectives}

* To assess the existing condition of water supply infrastructure and service delivery in Gimbi town.

* To assess the institutional frameworks and its capacity to deliver water supply infrastructure and service effectively.

* To identify factors responsible for the inadequate water supply infrastructure and service delivery.

* To assess the socio-economic impact of inadequate water supply on residents.

\subsection{Material and Methods}

\subsection{Description of the Study Area}

Historically Gimbi town was established in 1873, which is one of the towns found in Oromia National Regional State. During the Feudal and the Dergue administrative systems, Gimbi town, was a center of "Gimbi Awuraja or Gimbi Province". From 1991 onwards, it became the capital of West Wellega Zone. The town is found at a distance of $441 \mathrm{~km}$ from Addis Ababa to the West of Ethiopia along the main road that passes to Assosa and Dambi Dollo towns. Astronomically the town is found in between $9^{0} 10^{\prime} \mathrm{N}$ and $35^{\circ} 50^{\prime} \mathrm{E}$. In relative location, in all directions, the town is bounded by the Gimbi woreda.

The town is one of the second grade reform towns in the region; and sub-divided in to four kebeles for administrative purpose and has a status of local government. The built area of the town is estimated to be 1,200 hectares.

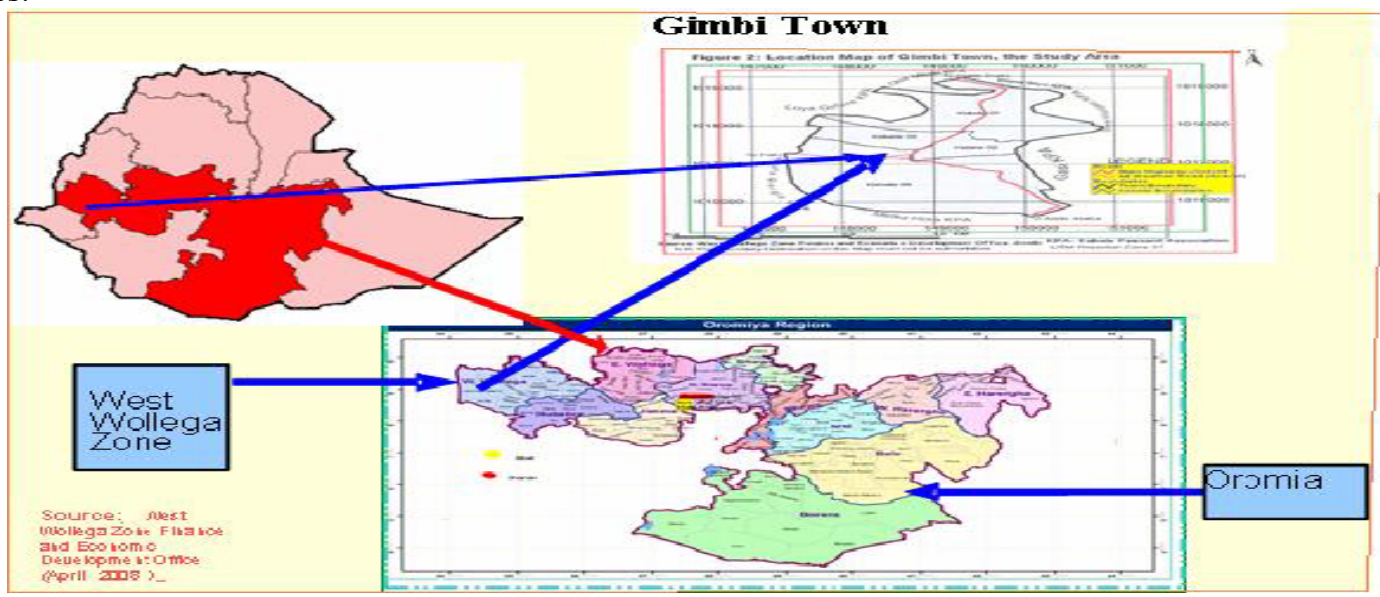

Figure 1-Map of Ethiopia, Oromia Regional State and Gimbi Town

\subsection{Definition of Various Terminologies}

i. Adequate Water: as to MoWR, 20 litres of water per person per day and accessible within a range of 0.5 to $1.0 \mathrm{~km}$ from a dwelling place is considered to be adequate (MoWR, 2001).

ii. Maintenance: refers to the activities aimed at keeping existing capital assets, in serviceable condition by repairing water distribution pipes, pumps, public taps etc.

iii. Operation: is activities aimed at running water supply and service delivery effectively.

iv. Unaccounted-for Water: is water that is pumped from a source but not sold to the customers. It is the difference between water produced and consumed (Buchberger \& Nadimpalli, 2004).

v. Water Distribution System: is the process of dividing up and giving out water among the customers (Larry, 2004). This covers the process starting from water treatment to piping.

vi. Water Quality: is water that is treated most commonly through the use of chlorination.

vii. Water Reliability: is defined as the probability of satisfying nodal demands and pressure heads for various possible pipe failures in the water distribution system at any given time. 
viii. Water Source: is the place where water has to be obtained, which include surface water,_under river flow, ground water, desalination and frozen water.

ix. Water supply infrastructure: include all the necessary physical components which are important to provide water to the customers e.g., pipe, pump, reservoir, treatment plant etc.

\subsection{Study Methodology}

Mixed research design is used, which involves both the qualitative and quantitative approaches in a single study. As Creswell explained, all methods have limitations and felt that biases inherent in a single method could neutralize or cancel the prejudices of other methods (Creswell, 2006). From different strategic models of mixed approach, the researcher selected descriptive design; collecting and analyzing quantitative data followed by collecting and analyzing qualitative data. With regard to the sources, both primary and secondary data were generated and used as an input for the research.

\subsubsection{Sampling Techniques}

The sampling techniques describe the population of interest, the sampling frame, methods of selecting the sample, and the sample itself. Hence the valuable information for the study was gathered in connection to the objective of the thesis. To conduct such kind of research, one obviously needs to collect primary data through field survey from each and every customer of the service. However, it was not possible that the researcher investigates all elements of the population through a census due to high costs, unavailability of time and large volume of data. Hence, the research focused on selected individuals and households. In order to draw the tangible information and reach at generalization, the researcher selected the samples that had the characteristics of representation.

For administrative purpose, the town is divided into four kebeles (the smallest administrative unit under town administration). That is, kebele 01, 02, 03 and 04. In order to select areas where the research is going to be conducted, they were clustered according to their characteristics to ensure homogeneity in the grouping of kebeles. Clustering was based on the population size, function of the area (residential or commercial), location in the town (periphery or center of the town) and the age of the area (old and new area). Accordingly, Kebele 01 and 04 has similar characteristics except the number of population. The same is true for Kebeles 02 and 03 . Thus, Kebele 01 and 04 are under the same cluster, while kebele 02 and 03 are the other cluster. In most cases, the majorities of Kebele $01 \& 04$ are residential and contain new settlement areas. On the other hand, the majority of kebele 02 and 03 are almost commercial and center of the town. Therefore, two Kebeles with the different characteristics that can represent the other, i.e., the more old and slum area (03) and the new establishment and expanding area (01) were selected. Based on non-probability sampling technique, from these clusters kebele 01 and 03 were selected as the study site (sample frames) because relatively these two Kebeles have acute shortage of water supply. These kebeles have a total of 4,395 households (HHs), which accounts for 56.14\% of the total households in the town and have the characteristics of representation.

In addition to the above method, households were stratified in order to get unbiased appropriate information about the problem of water supply infrastructure and service delivery of the town. The criterion for stratification method was based on the possession of private meter since it is taken as best standards of water supply service. Accordingly, while conducting an extensive survey, from kebele 01, 680 households with private house pipe connection and 1,643 households who have not private connection were identified from the list. The same thing was done for kebele 03, 840 households and 1,232 $\mathrm{HHs}$ who have and do not have respectively were selected. Depending on time and financial constraints, the researcher decided to carry out the study on the 5 percent of households in the selected kebeles that were proportionally included into the sample size. That is in kebele 01,34 and $82 \mathrm{HHs}$ with and without private pipe connection respectively and in kebele 03, 42 and $61 \mathrm{HHs}$ with and without private pipe connection respectively, which are 219 households. Finally, to select respondent household and proportionally include in the sampled kebeles, a list of the selected kebeles was used as a sampling frame. From that, the first number from each list was selected randomly through simple random sampling technique.

Besides, purposive sampling technique was also used in order to get more information about the study; from seven selected officials and professionals. That is, from Manager of the town water supply office, Administration and finance head, operation and maintenance department, Planning and Program department, the Town's Water Board, Human resource and Mayor of the town.

\subsubsection{Data Collection Methodologies}

For primary data collection, the structured questionnaires were prepared in English and translated into Afan Oromo (local language) for the local people to understand the questionnaires and then translated back into English for analysis and hence were distributed among the households. The questionnaires were both close and open ended to get information in accordance to the research objectives. To carry on the collection of data, the researcher employed five enumerators that were selected, trained and sent to the sample households after preliminary test of the questions under the supervision of the researcher. Finally, slight modifications were done on some questions to enable to meet the desired objectives. 
Since it provides richer information while collecting data, interview was used. Accordingly, structured and semi-structured interview questions were prepared to collect data from the officials of the town. The interview questions were prepared in English but latter translated to the local language (Afan Oromo) for the local officials and experts to communicate easily with the researcher and latter translated to English for the analysis.

Furthermore, during his stay in the field, the researcher tried to systematically observe realities on the ground to get primary information on the stated issues and to take sample photographs during site observation to describe and give more visualization on the existing situation. As the photographs are more expressing than raw data, and give more insights toward what the study area looks like, it was also used. To do this, the researcher prepared and used checklist to verify items of the existing situation of educational infrastructural services and facilities of the town.

\subsubsection{Data Analysis}

Collected data was sifted, collated and organized. To make the data meaningful for the analysis, data was processed by editing, coding, classification and tabulation. In general, data was analyzed by descriptive statistics. These data were presented by using tabular and graphic form where necessary. Ultimately, both the qualitative and quantitative data was appropriately interpreted in the way they give meaningful findings/outcomes for the readers. The qualitative data were interpreted by words particularly using coding, narrative and content analysis techniques. The quantitative data on the other hand were interpreted numerically by frequencies, percentages and averages.

\subsection{Results and Discussion}

\subsection{Socio-Economic Profile of Sampled Households}

Under this sub-topic, personal information of the households like: the sex, age, family size, level of education, occupation, average income of households, and ownership of the houses have been presented, which in turn can serve as a background for the issues to be analyzed.

To begin with, of the 219 respondents that are assessed through the survey, $74.43 \%$ (163) were males and $25.57 \%(56)$ were females. With regard to the age distribution, $30.9 \%$ of the HHs were the age between $18-30$ years, $44.3 \%$ of the respondents were between $31-45$ years and $24.3 \%$ of them were between $46-64$ years, whereas, $0.5 \%$ respondents were above 65 years old.

Concerning the household size, $49.32 \%$ (108) had family size ranging from $2-5,44.69 \%$ (101) were in the range 6-9 household size, 3.65\% (8) have confirmed their family size $10-13$ and the rest $0.91 \%$ (2) had household size more than 13, the mean size of the family is 5.56 persons (Table 4.6). With reference to their educational level, $25.57 \%$ (56) of the respondents are grouped in the range between $1^{\text {st }}-8^{\text {th }}$ class, $40.71 \%(92)$ of them were between $9^{\text {th }}-12^{\text {th }}$ class, $11.42 \%(25)$ of them were certificate holders, $19.18 \%$ (42) of them were diploma and above holders, while $1.83 \%$ (4) of them were illiterate.

Table 1: Ownership of House and Household Water Consumption (1/d/c) Gimbi Town

\begin{tabular}{llllllllll}
\hline $\begin{array}{l}\text { water } \\
\text { consumption } \\
\text { in } 1 / \mathrm{d} / \mathrm{c}\end{array}$ & \multicolumn{2}{l}{$\begin{array}{l}\text { Private owned } \\
\text { No. }\end{array}$} & $\begin{array}{l}\text { Rented from } \\
\text { government }\end{array}$ & No. & $\%$ & $\begin{array}{l}\text { Rented } \\
\text { private }\end{array}$ & No. & $\%$ & \multicolumn{2}{l}{$\begin{array}{l}\text { Use family's } \\
\text { House }\end{array}$} \\
$4-6$ & 51 & 23.29 & 34 & 15.53 & 17 & 7.76 & 8 & 3.65 \\
$7-9$ & 36 & 16.44 & 4 & 1.83 & - & - & - & - \\
More than 9 & 22 & 10.05 & 2 & 0.91 & 1 & 0.46 & 2 & 0.91 \\
\hline Total & 42 & 19.18 & - & - & - & - & - & - \\
\hline
\end{tabular}

Source: Field Survey, 2016

The sampled households have various occupations. These include civil servants, private business, daily laborers, employees of NGOs, farmers and others (pensioners and households that depend on other people for their survival). Out of the total of 219 sample households, 58.9\% (129) were civil servants for they constitute the dominant section of the town's population. Private businesses constitute $14.16 \%$ (31), whereas $10.5 \%(23)$ of the sample households were daily laborers, $2.74 \%$ (6) of them were employees of NGOs. The remaining $7.76 \%$ (17) are farmers, pensioners and dependent households which constitute $5.94 \%$ (13).

Regarding income of the sample households, $23.29 \%$ (51) of them earn less than 300 birr, $52.99 \%$ (116) get monthly income which ranges from birr 300 to birr 1500 . They were only $23.74 \%$ of the surveyed households that earn an income above 1500 birr (see Table 4.5). This shows most of the respondents are categorized in lower and middle-income group.

Questions that concern with the ownership of housing were also asked. This was done to identify if factors related to this affects households' water consumption due to lack of private meter, which in turn mostly resulting from lack of permanent residential area.

As shown in Table 1 above, out of the 219 surveyed households, $68.95 \%$ (151) of them reside in their own houses, whereas $26.48 \%$ (58) live in rented houses. The remaining $4.56 \%$ (10) are found to have lived in their 
family houses. It is evident from this that the majority of the households have their own private houses. The rate of water consumption also increased among those living in their own houses. Therefore, though there are also other factors, house ownership affected the amount of water consumption in the town.

\subsection{Existing Situation of Water Supply Infrastructure and Service Deliveries to the Sampled Household 5.2.1 Source of the Existing Water Supply Service}

Water sources as points of water collection include surface water, ground water and rainwater harvesting. The current predominant existing water source for Gimbi town is Gefere River, which is located at the down western side of the town and is termed as surface water. In addition to this, there were also other sources that the residents used for domestic consumption among which rivers, streams, and rainwater are the main one. The details of water supply sources are given in table 2, below;

Table 2: Water Supply Sources of Gimbi Town

\begin{tabular}{lccccc}
\hline Types of Services & Private metered & Public fountain & $\begin{array}{l}\text { Other Sources } \\
\text { (river, stream \& rain) }\end{array}$ & Water Vender & $\begin{array}{l}\text { Total } \\
219\end{array}$ \\
\hline Frequency & 76 & 116 & 18 & 9 & \\
Percentage & 34.7 & 52.97 & 8.22 & 4.11 & 100 \\
\hline
\end{tabular}

Source: Field Survey, 2016

As can be observed from Table 2, the type of water supply source the households use indicated that, $34.7 \%$ get water from private meter connection, $52.97 \%$ of them from private tap, $4.11 \%$ get from vendors and $8.22 \%$ collect from others, which are unprotected sources. As to the above table, the majority of the respondents use piped water distribution. However, it is not used regularly and for all household purposes due to inadequacy and frequent interruption. Therefore, the town residents use multiple sources of water to satisfy their daily demand. This implies that in Gimbi town, most people utilize several sources of water, which are not safe and adequate to satisfy their daily needs.

\subsubsection{Reasons for Using Diverse Sources of Water}

As observed from table 2 above, from the total surveyed households, $8.22 \%$ (18) of them are completely relying on other sources, which are qualitatively unimproved. During the course of survey, they were interviewed the reason why they use such sources and in accordance to this, $38.89 \%$ (7) of the households said piped water is expensive, while $61.11 \%$ (11) households responded that there is no pipe distribution around their residence. This indicates that lack of distribution network and the existing price of piped water to be factor hindering the dwellers from using improved water sources.

On the other hand, those termed as pipe water users were also found to be other source users. Therefore, they were also asked the reason why they use these sources. In this regard, many reasons could be listed including lack of consciousness of understanding about the difference between safe and unsafe water. But, the main reasons given by respondents of pipe water users for collecting water from these sources were listed in Figure 2 below.

Figure 2: Reasons for Using Diverse Sources of Water in Gimbi Town

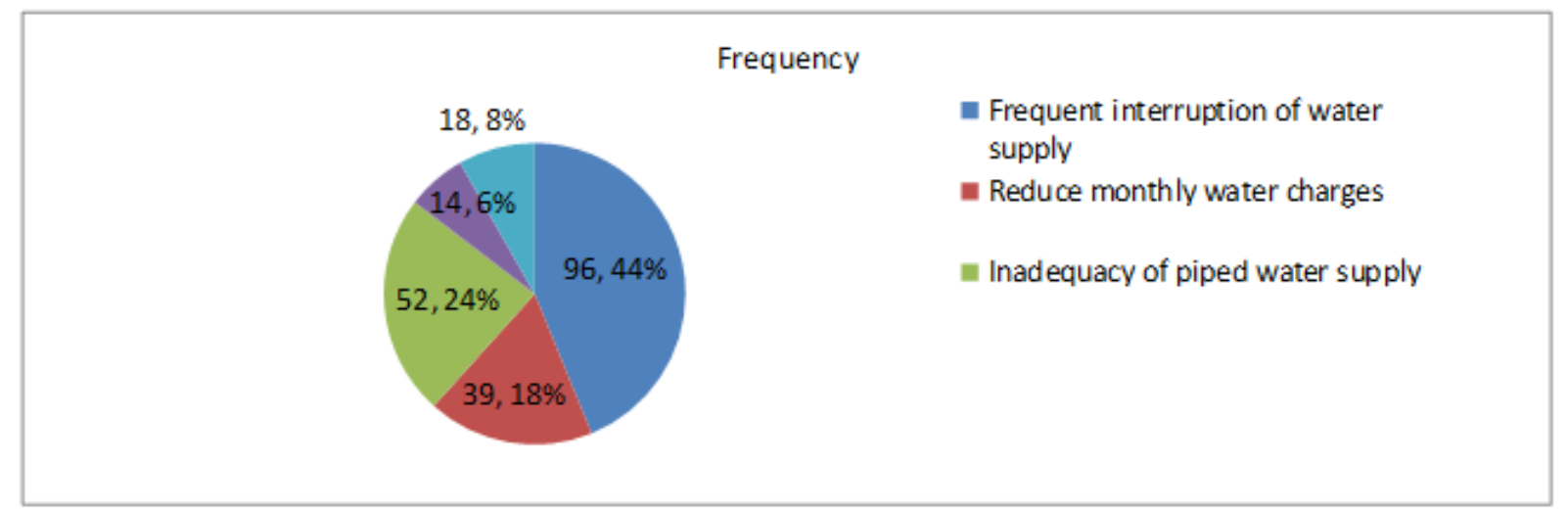

Source: Field Survey, 2016

As indicated in Figure 2, the main reasons for using diverse sources is frequent interruption of piped water supply service intermittent water supplies as identified by $44 \%$ of respondents, which is the major factor to collect from unsafe source, and followed by inadequacy of piped water supply. This testifies as the existing conditions forced the residents to use diverse sources.

\subsubsection{Water Supply Distribution Network System}

Distribution is a process of transporting water through the supply system to the end users. It is the means by which the available water is provided to the people. In this case, Gimbi water supply distribution starts from the Gefere River, which is surface water. The intake site is equipped with electrical pumps and is connected to the 
national hydro-electrical grid to pump the water from the source to the treatment site and then to the consumers.

Regarding water distribution, secondary data obtained from Gimbi town water supply and sewerage service office (WSSS) reveals, the treated water is distributed to the consumers through 2,847 private connections (2618 for residential consumers, 159 for business organizations and 52 for government offices and 38 for NGOs), and 27 public standpipes. All the existing public standpipes deliver service by two or more shifting systems.

In short, water distribution system is the process of dividing up and giving out water among the customers. These systems are composed of three major components: Pumping stations, distribution storage and distribution piping. In case of Gimbi town, the distribution system is single lined that means, water from the treatment site is pumped to the customers and to the reservoirs through the same line and at the same time. This means, water is distributed to the customers directly from the station through distribution piping and at the same time little quantity flows to the reservoirs that serve residence of higher altitude where pumping power cannot reach violating the existing theory on water distribution system. Therefore, all areas of the town could not get equal and proportional service. Due to this, the people of higher topographical areas, the peripheral and newly expanded areas of the town lack the service. As a result, as observed by the researcher during the survey, peoples living in these areas were forced to go far distance in search for water.

Those respondents who privately connected to the existing water supply were asked whether their water meter is functioning or not, and many of them $(97.37 \%) 74$ households responded that it is functional except two respondents $(2.63 \%)$ who were suspecting their meter.

\subsubsection{Drinking Water Treatment Plant}

As it was noted, the source of the town's water supply is surface water i.e., from Gefere River. The treatment plant design was slow sand filter with horizontal roughing filter as a pre-treatment unit. Because of turbidity problem particularly during the rainy season, the roughing filter unit has been frequently clogging; as a result it is abandoned. To alleviate the problem of turbidity, chemical coagulation system is incorporated and the roughing filter box is used as sedimentation tank. Thus, at present from the wet well, the raw water is pumped into a compartment where it is mixed with Aluminum and Sulfate to the sedimentation tank and then to slow sand filter unit. Treated water from the drainage system of the slow sand filter is drained into temporal storage area. The slow sand filter has two compartments each having four partitions, which are used alternatively during re-sanding. From the clear tank after treated with chlorine, the water is pumped to the distribution system and the remaining water from consumer will be stored in the reservoirs. The pipeline network consist loop and branch system, which is backward system catering the water through public fountains and private pipe.

\subsubsection{Water Storage Reservoirs}

Reservoir as part of the distribution system is to guarantee a continuous supply of water at the time of interruptions in the process of production. In Gimbi town, the existing reservoirs serve limited households who live on higher altitude where the distribution pump cannot reach, especially kebele 03 and 04 . Secondary data obtained from Gimbi water supply service office shows the water supply system of the town consists of two reservoirs. The capacity of these reservoirs is $150 \mathrm{M}^{3}$ and $400 \mathrm{M}^{3}$, where the smaller reservoir gets filled after the bigger reservoir. Besides the limited capacity of the reservoirs, during field observation, the existing reservoirs were found to be almost empty, as water is collected only when there is low consumption. The situation calls for redesigning the system and establishing additional reservoirs.

\subsubsection{Service Delivery Coverage through Existing Water Supply Infrastructure}

Water supply coverage provides a picture of the water supply situation of one specific town. The percentage of population with or without piped water connection is an indicator to compare the coverage of water supply in the town. The entire part of town is not covered by pipeline, rather some part of the town has relatively better network while some part of the town is not. This is particularly true for peripheral areas, which are currently beyond the reach of the service. People living in such areas of the town suffer from absence of water supply around their residence. They usually go far off distances in search of water and carry it along in spending much time even in queuing up near the water taps.

Regarding water distribution of the town, as previously discussed, there are 2847 private connections and 27 public standpipes, out of which two of them were not functioning. The 27 public fountains are estimated to serve 2,700 households (HHs) or 13,500 people, i.e., one fountain for $100 \mathrm{HHs}$ or 500 people. However, according to the standard set by World Food Organization, 27 standpipes can serve maximum of 5,400 people or $200 \mathrm{HHs}$, i.e., one for 200 people or $40 \mathrm{HHs}$. This indicates additional 40 public standpipes are required in the town. The details of distribution are shown in table 3 below; 
Table 3: Distribution of public fountains and Private meter connections within the Kebeles of the Town

\begin{tabular}{lllllll}
\hline Kebeles & \multicolumn{2}{l}{ Public fountain } & \multicolumn{2}{c}{ Households with Private } & \multicolumn{2}{c}{ Households without private } \\
& & & \multicolumn{2}{c}{ meter connection } & \multicolumn{2}{c}{ meter connection } \\
& No. & $\%$ & No. & $\%$ & 1,643 & 70.73 \\
\hline 01 & 5 & 18.52 & 680 & 29.27 & 944 & 60.82 \\
02 & 8 & 29.63 & 608 & 39.18 & 1,232 & 59.46 \\
03 & 7 & 25.93 & 840 & 40.54 & 1,391 & 73.95 \\
04 & 7 & 25.93 & 490 & 26.05 & 5,210 & - \\
Total & 27 & 100 & 2,618 & - & & \\
\hline
\end{tabular}

Source: Computed from Gimbi town WSSS Office and Field Survey, 2016

As indicated in Table 3, the rate of meter connection is low when compared to the number of inhabitants living in each kebeles. More than $66 \%$ of the households were without private connection. In addition, there is also variation among the kebeles in the proportion of households with private meter connection service, which is emanated from either of differences in income levels, limited pipelines network and insufficiency of the existing source and distance from it. It also reveals, the distribution of public fountains within the kebeles did not take into consideration the number of people, density and distance between water points. Above all, there is limited numbers of public fountains when compared with the numbers of users. As a result, inhabitants have to take their jerry can early of the beginning of service and form waiting line at water points and when queue jumping occurs among those waiting turn, dispute may take place. Thus, to make the inhabitants beneficiaries of the service, it needs making the distribution equitable and increase the coverage, which generally requires redesigning the distribution system and then establishing additional distribution pipelines.

In general, when compared with urban areas in Ethiopia, which is $72 \%$, the water supply coverage of the town is low as it is only $30.39 \%$. And even the coverage in the sample kebeles is lower than this signifying low coverage and overcrowding at public tap shown by the plate 1 below.

Plate 1: Sample photos of Public Fountain Users Queuing at Water Point in Gimbi Town

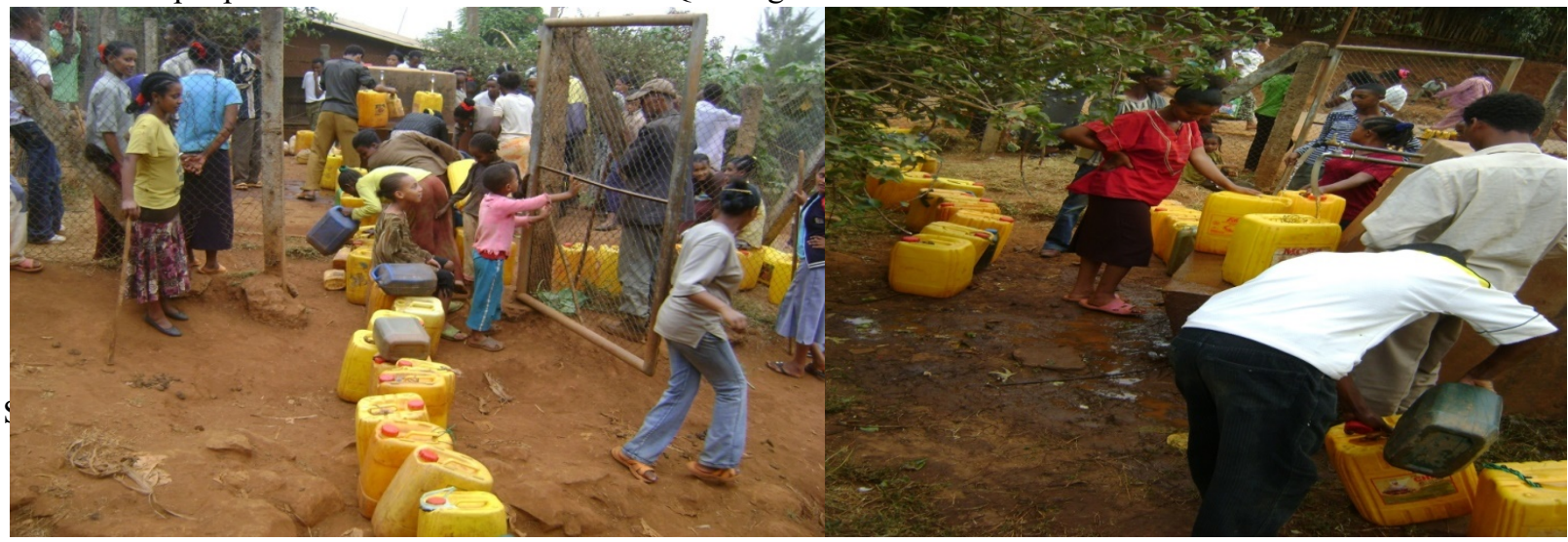

Access to water supply is mainly concerned with the average distance of water point and the time spent in collecting the available water. The HHs who are absolutely dependent on other sources than pipe water, public tap and those who use from private meter were asked about the distance traveled and the frequency to fetch water per day from these sources.

Regarding this, other source users that account to $37 \%$ said it takes more than 1 hour, $26 \%$ responded 40 minutes, $18 \%$ said 30 minutes and $11 \%$ responded it takes 20 minutes. The rest that accounts $8 \%$ replied as they do not know how much minutes it takes. From this, it is evident that about $81 \%$ of the households travel a distance of 30 minutes and above for a single trip and are required to fetch from these sources frequently 5 times per day on average.

Households those who collect water from public tap were also asked. Pertaining to this, their response about the distance taken including waiting for turn to fetch water ranges from 15 minutes to 30 minutes. This is only when there is an availability of water in the pipe that the customers waste this time; otherwise it takes the above noted time replied by those who fetch from rivers. The frequency of collecting from this source is 8 times per day on average.

The above data reveals that the distances the HHs are forced to cover and the time they spend is greater than the reasonable access recommended by MoWR. In general, the public fountain users walk longer distance and waste longer time than the private pipe users. Whereas, other sources users (rivers and streams) walk longer distance and time than public fountain users. This indicates that all people have no equal chance of access to water supply service showing inequitable distribution of water supply infrastructure and service delivery among the households. 


\subsubsection{Reasons for not Having Own Connection}

Distributing water through house connection use is obviously the most convenient system of water supply for households. However, the installation of the residential meter connection involves much higher cost which the households, especially the poor could not afford. Households that do not have private access to piped water were asked the reason why they do not privately connected to the existing water supply system. Accordingly, 50.35\% (72) of the respondents said the reason is due to high connection cost, 39.16\% (56) of the respondents said because they do not have their own house, these are out of the 68 households who confirmed that the houses in which they are living are not theirs, and the other reason, which was given by $10.49 \%$ (15) HHs is the town water supply office told them it is not possible to get private connection at this time due to far from pipeline. From this, it can be inferred that high cost of new installation is the number one obstacle followed by lack of own house and others respectively for not having own meter connection, which could be attached to the income level of the surveyed households.

Information pertaining to the criteria required from the households for new connection was obtained from the Gimbi town WSSS office. Correspondingly, as to the information obtained indicates the first criteria are the customer has to have a legal document from the town's municipality, which shows the legal ownership of the house to which connection is required. After doing so, if the house is located within the already existing distribution pipeline, an applicant has to pay a minimum of 600.00 ETB. So, this clarifies the house ownership and cost are factors hindering the households from connecting private pipe. The other factors identified are the mismatch between the existing water distribution network and town's expansion i.e., majority of new settlement areas are out of the reach of the distribution network coverage making the new connection more challenging in the surveyed kebeles. In general, the rate of meter connection is low, which is $22.57 \%$ for the town.

\subsubsection{Water Production, Consumption and Unaccounted-for Water (UfW)}

\subsubsection{Water Production}

Water production is the water produced and available for consumption and is conceived as free from organisms and concentration of chemical substances that may be hazardous to health. Unfortunately, Gimbi water production from Gefere River has high turbidity. As all the wastes from the town drain it, it is conceived as polluted though it is treated with chemicals. The water produced at the source is distributed to the customers and consumption is read from the water meters installed at customers and public fountains.

As shown in table 4 below, production of the town's water increased from 132,099 $\mathrm{M}^{3}$ in 2007 to 194,700 $\mathrm{M}^{3}$ in 2016, the difference being 62,601 $\mathrm{M}^{3}$. However, increment in the rate of production and consumption do not match each other. This implies, with the current production rate, the water supply of the town cannot provide the growing population. So, to further explain this, it is necessary to look at demand and supply of water service in the town.

Table 4: Water Produced, Consumed and UfW in Gimbi Town (2007-2016)

\begin{tabular}{cllll}
\hline Year & $\begin{array}{c}\text { Water Produced } \\
\text { in } \mathrm{M}^{3}\end{array}$ & $\begin{array}{c}\text { Water Consumed } \\
\text { in } \mathrm{M}^{3}\end{array}$ & $\begin{array}{c}\text { Water Loss in } \mathrm{M}^{3} \\
(\mathrm{UfW})\end{array}$ & Water Loss in \% \\
\hline 2007 & 132,099 & 75,137 & 56,962 & 43.12 \\
2008 & 149,981 & 87,112 & 62,869 & 41.91 \\
2009 & 163,354 & 96,016 & 67,338 & 41.22 \\
2010 & 163,520 & 92,264 & 71,256 & 43.58 \\
2011 & 168,757 & 94,348 & 74,409 & 44.09 \\
2012 & 171,815 & 91,965 & 79,850 & 46.47 \\
2013 & 172,039 & 107,290 & 64,749 & 37.64 \\
2014 & 178,274 & 112,427 & 65,847 & 36.94 \\
2015 & 177,686 & 102,973 & 74,713 & 42.05 \\
2016 & 194,700 & 122,863 & 71,837 & 36.90 \\
\hline Total & $1,672,225$ & 982,395 & 689,830 & 41.25 \\
Average & $167,222.5$ & $98,239.5$ & 68,983 & 41.25 \\
\hline Sour & Compus & & \\
\hline
\end{tabular}

Source: Computed from Gimbi Town WSSS Office, 2016

Population, nature of consumption and water loss (UfW) is the main determinants of water demand. According to Gimbi town administration, the population of the town in 2016 is estimated to be above 100,000. As to the MoWR (2001); Water, S \& World Health Organization (2004), and), 50 and 20 1/d/c respectively is basic access of water in urban areas. According to these organizations, the demands of water for domestic use of Gimbi town should be $2,900 \mathrm{M}^{3}$ and $1,160 \mathrm{M}^{3}$ of water per person per day respectively. On the contrary, the average water supply of the town which reaches the final customer is $352.5 \mathrm{M}^{3}$ per day. As to this data, 2,547.5 $\mathrm{M}^{3}$ and/or $807.5 \mathrm{M}^{3}$ of water per day respectively are additionally needed to meet the current daily domestic demand of the people.

Therefore, it can be deduced that with the current production rate, the water supply of the town cannot provide the growing population. There is mismatch between supply and demand of water in the town. Because of 
this, as stated above, almost all the sampled households who were taken as piped water users collect water from other sources. In general, limited source coupled with frequent interruptions and unfair distribution of water points on the one hand and the growing needs on the other hand are ever widening the already existing unbridgeable gap between the demand for and supply of water in Gimbi town.

\subsubsection{Water Consumption}

As indicated in table 5, consumption of water in the town increased from $75,137 \mathrm{M}^{3}$ in 2007 to $122,863 \mathrm{M}^{3}$ in 2016, the difference being $47,726 \mathrm{M}^{3}$. However, the per capita consumption of HHs remained to be very low. This can be confirmed by the fact that the $1 / \mathrm{c} / \mathrm{d}$ of $2009 / 10$ is 6.08 liters, which is calculated for domestic use only. Data obtained from the sampled HHs with regard to the amount an individual HH consumes differs according to the type of source used. In relation to this, as the survey data shows the daily water consumption of the HHs who have private connections was more than $6 \mathrm{l} / \mathrm{d} / \mathrm{c}$ while those without private meter connection was 1-5 l/d/c (see table 5). This illustrates people without own connection consume less water compared to those with private connection. This is because public tap users and those collecting from rivers or streams have to travel longer distance, have to wait turn, and also inconveniency of the time.

Besides the type of sources $\mathrm{HHs}$ use, the socio-economic factors also affect the rate of $\mathrm{HH}$ water consumption. Among the socio-economic factors that affected water consumption, the growth of the town population, $\mathrm{HH}$ income, family size and house ownership are the main one that needs to be considered. The level of income of the HHs is one of the factors determining water consumption, private meter connection and expenditure on water supply service.

Table 5: Household's Average Monthly Income, Pipe Water Consumption per person per Day in Liters, Private Meter Connection and Monthly Expenditure on Water Supply Service

\begin{tabular}{lllllllll}
\hline \multirow{2}{*}{$\begin{array}{l}\text { Income in } \\
\text { birr }\end{array}$} & \multicolumn{2}{c}{ Household } & \multicolumn{3}{c}{$\begin{array}{l}\text { Consumption } \\
\text { in liter }\end{array}$} & \multicolumn{2}{c}{$\begin{array}{l}\text { Private meter } \\
\text { connection }\end{array}$} & \multicolumn{2}{l}{$\begin{array}{l}\text { Expenditure per month on water } \\
\text { supply service }\end{array}$} \\
& No. & $\%$ & Per person & No. & $\%$ & In birr & No. & $\%$ \\
\hline$<300$ & 51 & 23.29 & $1-5$ & - & - & $2-10$ & 67 & 30.59 \\
$300-700$ & 55 & 25.12 & $6-10$ & 16 & 21.05 & $11-20$ & 75 & 34.25 \\
$701-1100$ & 44 & 20.09 & $11-15$ & 27 & 35.53 & $21-30$ & 28 & 12.79 \\
$1101-1500$ & 17 & 7.76 & $16-20$ & 13 & 17.11 & $31-40$ & 15 & 6.85 \\
$>1500$ & 52 & 23.74 & $>20$ & 20 & 26.32 & $>40$ & 34 & 15.53 \\
\hline Total & 219 & 100.00 & - & 76 & 100.00 & - & 219 & 100.00 \\
\hline
\end{tabular}

Source: Field Survey, 2016

As indicated in Table 5, about half of the surveyed households earn less than 701 ETB and their per capita water consumption from piped water was found to be between 1-10 liters per day. Those households whose income is greater than 701 birr consume greater than $10 \mathrm{l} / \mathrm{d} / \mathrm{c}$, however, per capita water consumption of the majority is lower than the acceptable standard of MoWR and WHO. It is also true that respondents who earn less than 701 birr have low access to private meter connection as they were only $21.05 \%$. Likewise, $64.84 \%$ households who earn the stated income spend less to potable water, which is 2-20 birr per month. This shows there is relative increase in daily per capita water consumption from lower income to higher income respondents. At the same time, those HHs who earn relatively higher income have access to private meter connection since they could afford cost of installation and also their monthly expenditure for piped water was relatively high. So, it can be inferred that monthly income, water consumption, meter connection and expenditure for potable water supply are strongly related and hence, the level of income HHs earn affected consumption of water in Gimbi town.

One of the factors affecting water consumption in the study area is the number of families the households have as presented in Table 6 . There is a strong relationship between family size and amount of water consumption in the study area. As indicated in Table 6, 48 \% (106) of HHs having 2-5 family size consume 1-6 liters of water per day, except two HHs within the range who consume 7-9 liters. On the other hand, those above 6 family sizes consume more than 6 liters of water per day. It is evident from this data that, as the HH size increases, the daily water consumption per $\mathrm{HH}$ also increases. So, household size is one of the factors affecting the rate of water consumption in Gimbi town.

Table 6: Family Size and Households' Pipe Water Consumption (1/d/c), in Gimbi Town

\begin{tabular}{|c|c|c|c|c|c|c|}
\hline \multirow[t]{2}{*}{ Size of the Families } & \multicolumn{5}{|c|}{ Household Water Consumption( $1 / \mathrm{d} / \mathrm{c}$ ) } & \multirow[t]{2}{*}{ Total } \\
\hline & 1-3 liters & 4-6 liters & 7-9 liters & 10-12 liters & $>12$ liters & \\
\hline $2-5$ & 51 & 55 & 2 & - & - & 108 \\
\hline $6-9$ & - & - & 42 & 17 & 42 & 101 \\
\hline $10-13$ & - & - & - & - & 8 & 8 \\
\hline$>13$ & - & - & - & - & 2 & 2 \\
\hline Total & 51 & 55 & 44 & 17 & 52 & 2019 \\
\hline
\end{tabular}

Source: Field Survey, 2016 


\subsubsection{Unaccounted- for Water (UfW)}

Unaccounted-for water is water that is pumped from a source but not sold to customers largely because of problem within the distribution scheme, system failures, meter error, age of pipes, and distribution losses through leaks from mains, theft etc. There are also other reasons like water used for fighting fires, dust control, flushing mains to maintain drinking water quality etc. that contribute to UfW. It is calculated from the total production and consumption of water, which can be obtained by subtracting the actual production from consumption. As Table 4.4 shows, from the year 2007 to 2016, a total volume of 1,672,225 $\mathrm{M}^{3}$ of water produced and only $982,395 \mathrm{M}^{3}$ of water used by the customers. The difference $689,830 \mathrm{M}^{3}$ or $41.25 \%$ of the total water produced were lost through various ways (Table 4.4). Due to this, the utility is losing about half a million ETB per annum. This condition is in line with the existing theories forwarded by Arlosoroff and WHO and hence, as the situation is true in so many developing cities, UfW is reducing HHs domestic consumption in Gimbi town and also reducing revenue of the sector.

In order to identify the factors contributing to UfW (water loss), interview was conducted with the O\&M department of Gimbi town WSSS. The response obtained shows the major cause for the UfW are: leakage from mains, joints, valves, hydrants and washouts, and leaks from service pipes, consumer's meters, and etc. The other cause of water loss through leakage is aging infrastructure, especially in kebele 03 and 04 ; high traffic and material composition like soil and stone accumulation, especially along the highway where main pipelines are found, inadequate corrosion protection, mechanical damage, quality of technicians and equipment are among others. Meter error, illegal installations and theft are also some of the factors for water lose in the town.

\subsection{Institutional Framework and Organizational Capacity for Service Deliveries 5.3.1 Institutional Frameworks of Gimbi Town WSSS Office}

In Ethiopia, Ministry of Water Resource is the body responsible to set all rules concerning water supply and its uses. Nowadays, as a result of decentralization, the Regional governments are responsible for the development; operation and maintenance of rural and urban water supply systems in their regions. In this case, Oromia Water Resource Bureau is the body responsible to control and facilitate all the activities. The O\&M of urban water supply facilities are the responsibility of the town water supply service. In line with this, the responsible organ for town water supply is Gimbi Water Supply, Sanitation and Sewerage Service office, which is responsible for all O\&M and management of the town water supply system. At present, Gimbi town WSSS office is organized as autonomous public organization under the town administration and managed by Water Board whose chairperson is the Zonal Water Resources office head and the utility head being the secretary. The Town Water Board is the higher responsible organ for management including budget approvals for the Gimbi WSSS office. In addition to these, the town water board consists of members from the municipality, town education office, town women affair, town health office, town finance office, EEPCO office at Gimbi, and two representative of the community.

Organizational Structure of Gimbi Town WSSS Office

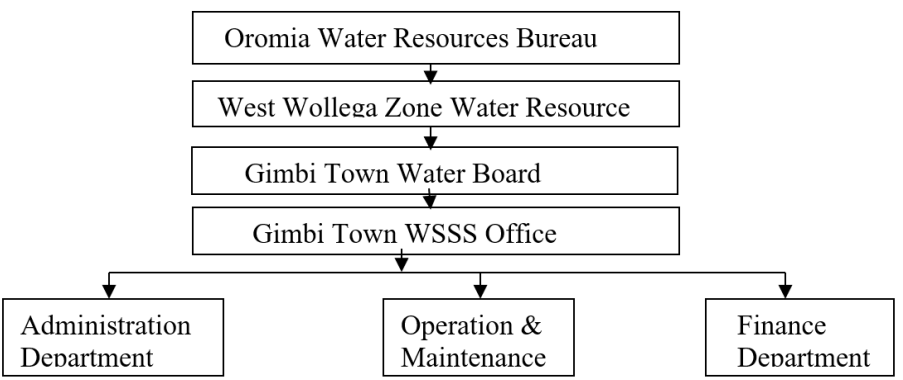

Figure 3: Organizational Structure of Gimbi Town WSSS Office, 2016

Source: Gimbi Town Water Supply Office, 2016

\subsubsection{Organizational Capacity}

One of the policy issues of water supply is to build technical, material, financial and human capacity of water supply office. In this regard, all maintenance works are done within the capacity of the utility. However, the office lacks skilled manpower in the field of water management. It also lacks technological equipment, budget and other necessary facilities.

This is evident from that, out of the total 45 workers, $46.67 \%(21)$ of them are $10^{\text {th }}$ and $12^{\text {th }}$ grade education, $31.11 \%$ (14) of workers are diploma holders, certificate represent $17.78 \%(8)$, and the rest that accounts only $4.44 \%$ (2) have first degree. This shows the office has shortage of skilled manpower especially at the position demanding relevant qualification. As information obtained shows the office encounters multiple problems. These are shortage of skilled manpower, lack of sufficient equipment, shortage of finance and lack of training programs and appropriate incentives are some of the problems identified by the utility sector. 


\subsubsection{Financial Capacity of Gimbi Town WSSS Office}

Revenue is the means that facilitates water supply O\&M and expansion of new establishments. The WSSS office of Gimbi town has the duty to raise adequate revenue and finance to deliver water supply services for its urban inhabitants. However, lack of sufficient financial and then that of material equipment, spare parts and machines has been a hindering factor. The important revenue source of the sector for financing water supply service is the revenue generated from water sales and meter rent including service charges from both private connection and public tap, which is illustrated in the following table 7.

Table 7: Revenue and Expenditure of Gimbi town WSSS Office (2009- 2016)

\begin{tabular}{lccc}
\hline Year & Revenue in ETB & Expenditure in ETB & Surplus/Deficit in ETB \\
\hline 2009 & $464,592.60$ & $393,476.54$ & $71,116.06$ \\
2010 & $571,706.54$ & $723,022.79$ & $-151,316.25$ \\
2011 & $693,793.02$ & $636,610.25$ & $57,182.77$ \\
2012 & $613,462.02$ & $602,724.65$ & $10,737.37$ \\
2013 & $673,424.07$ & $607,679.86$ & $65,744.21$ \\
2014 & $841,396.60$ & $829,128.14$ & $12,268.46$ \\
2015 & $922,088.20$ & $901,799.20$ & 20,289 \\
2016 & $1,014,536.57$ & $923,925.84$ & $90,610.73$ \\
\hline
\end{tabular}

Source: Gimbi Town WSSS Office, 2016

The above data indicates that, the WSSS office of the town was deficit only for the years 2010, while it was with surplus revenue for other years. In spite of this, the utility office could not expand the service coverage to expand the service to people in the periphery and outside of the network coverage in order that all the customers get access to adequate supply.

\subsubsection{Intermittent Water Supply}

All the data obtained reveals that the intermittent water supply service is predominant in the study area. For that matter, as the shifting system is applied in the distribution of water supply of the town, it is unquestionable about the interruption of water supply service. As to seasons of interruption, all witnessed that, it occurs during both the rainy and dry seasons, but the problem is much more serious during the dry season than the rainy season. This is because; during the rainy season the majorities have various options amongst collecting rainwater.

Other than mere interruptions, the frequency and duration of interruption show how service of water supply is poor in Gimbi town, which is shown by table 8 .

Table 8: Frequency of Water Supply Service Interruption in the Surveyed Kebeles

\begin{tabular}{ccccc}
\hline Interruption & Frequency & $\%$ & Valid \% & Cumulative \% \\
\hline Daily Once & 30 & 13.7 & 13.7 & 13.7 \\
Twice Daily & 47 & 21.5 & 21.5 & 35.2 \\
Three Times Daily & 35 & 16.0 & 16.0 & 51.1 \\
Unpredictable & 89 & 40.6 & 40.6 & 91.8 \\
Non Response & 18 & 8.2 & 8.2 & 100.0 \\
\hline Total & 219 & 100.0 & 100.0 & - \\
\hline
\end{tabular}

Source: Field Survey, 2016

Out of the surveyed households who confirmed interruption of water supply service, $40.6 \%$ claimed that the frequency of water interruption is unpredictable. As to them, it occurs from time to time and hence failed to confidently tell the time of the availability of the service. The rest replied an interruption that ranges from daily once to three times daily. This shows interruption is one of the factors contributing to insufficiency of water supply in the town.

Over and above the frequency of the most important service interruption, it is important to look at its maximum duration to reflect intensity of the problem. In this regard, of the sample households, $25.57 \%(56)$ of respondents revealed the duration of water interruption is unknown, which cannot be exactly determined. Whereas, 24.66\% (54) claimed five days duration per week, 20.09\% (44) households replied one day interruption, $15.98 \%$ (35) one week, 5.48\% (12) claimed interruption of two weeks and the rest $8.22 \%(18)$ did not respond, which represents those who were not customer of the service. This indicates other than interruption; the longer time it takes to deliver service highly affects the residents of the town.

The shortage of water supply is much grim for hotels and restaurants since they cannot provide potable water for their customers particularly of travelers. As observed during the survey; all restaurants, cafes and hotels in Gimbi town let alone giving glass of water for drinking; they do not even provide sufficient water for washing of hands before and after meal. Therefore, the customers are forced to buy soft drinks to satisfy their thirst.

\subsubsection{Alternative Water Supply Options}

At the time of water supply interruption, the inhabitants use different sources, which could be understood from 
the reply of informants: $94.52 \%(207)$ of the surveyed HHs replied that their alternative source is streams and rivers. A small proportion of households $5.48 \%$ (12) use their own tankers. Only $1.37 \%$ (3) HHs were identified as hand dug well users during interruption. This indicates that the residents of the town use unprotected sources to satisfy their daily demand of water supply service, due to the fact that the town's water supply service is not reliable.

Thus, HHs travel long distances to get water from the other sources. During this condition they are females who carry high responsibility to collect water from these sources. In general, HHs encounter various problems such as deserving costs and wasting time at water point as well as being exposed to various health hazards. This situation creates special burden on HHs who are completely dependent on unprotected sources for their daily demand of water supply service. This is because the water point will be crowded for that they have to wait long time. This needs the HHs to have reservoirs to gather water and also construct ponds to collect rainwater to solve shortage of water during unexpected interruption. Otherwise, their fate will be traveling long distance and staying for long time to collect water.

As to the view of the researcher, protecting these sources from contamination can alleviate the prevailing problems. This involves making such sources safe through different mechanisms such as chlorinating the sources. Furthermore, adapting the culture of boiling and filtering, fencing the areas and using them for functions other than drinking and cooking can reduce the burden of demand on pipe water supply in minimizing the problem of inhabitants at the time of pipe water interruption.

\subsubsection{Existing Water Supply Services Tariff}

In order to provide efficient and sustainable service, there should be a strategy to recover all the costs needed, as government cannot provide all the services required. Through setting tariff the users can be charged to generate revenue, which is supported by the Ethiopian Water Sector Strategy under the country's Water Policy. In case of Gimbi town, the utility office is expected to cover all costs including costs for operation (fuel, staff salaries, and cost of water treatment chemicals) and maintenance costs (labor, tools, equipment, spare parts). They recover all the costs from the revenue generated after being approved by the Town Water Board.

Regarding this, both secondary and primary data were used to analyze the existing tariff of the town. As secondary data obtained from the water supply office indicates, the water tariff of Gimbi town is progressive. It follows the block system and is divided into four blocks.

Table 9: Existing Tariff of Gimbi Town Water Supply Service

\begin{tabular}{lcc}
\hline Blocks & Consumption Range in $\mathbf{M}^{\mathbf{3}}$ & Tariff in ETB \\
1 & $0-5$ & 4.50 \\
2 & $6-10$ & 5.60 \\
3 & $11-30$ & 6.50 \\
4 & $>30$ & 7.00 \\
Public fountain & $1 \mathrm{M}^{3}$ & 2.75 \\
\hline
\end{tabular}

Source: Gimbi Town WSSS Office, 2016

Primary data obtained from the households regarding water tariff of the town reveals that only $7.76 \%(17)$ of the total surveyed respondents said that the existing water tariff is fair and affordable. All of these respondents are businessmen who are engaged in hotel and restaurants and also those HHs at better condition in terms of property they have. Information obtained from the majority, i.e., 92.24\% (202) shows, the existing water tariff is unfair and hence unaffordable. There are also some informants that compare the tariff of Gimbi town water with the oil gas. For those who use water by buying from vendors, the price is relatively higher than the existing government water tariff as they sale it on average a bucket (20 liters) of water for 0.75 birr (excluding cost of labor and/or transportation). This in general implies, the attitude of the people towards the current water tariff is negative as the majority responded that the current water tariff is unfair and unaffordable on the ground that the town water supply service is not reliable, low quality and quantity.

As it was presented in the previous section, the existing physical conditions of the distribution systems are an important determinant of water supply and service delivery in terms of quality, quantity and reliability. Regarding this, households were encouraged to provide information about the level of service in terms of quality, quantity and reliability. Accordingly, concerning the quality, quantity and reliability of the existing water supply system, the survey results indicate that only $31.96 \%$ (70) of the total respondent ranked the quality as good, and the rest $42.92 \%(94)$ and $25.11 \%$ (55) said that it is satisfactory and poor respectively. Regarding the quantity of water supply, only $6.39 \%$ (14) of the total respondents said it is sufficient and the rest $93.61 \%(205)$ said it is insufficient.

In terms of reliability, only $7.31 \%$ (16) respondents said that the existing water supply is reliable and $92.69 \%$ (203) said it is unreliable. Hence, due to its unreliability, most of the time the inhabitants are exposed to additional expense in terms of cost, energy and time in search of water from far distance. From this, one can deduce that the water supply and service delivery of Gimbi town is below an acceptable standard in terms of quality, quantity and reliability. 
A question related to the quality of water was requested to know whether the households use any purification method before they use for domestic purpose. The bulk of respondents, including the $18 \mathrm{HHs}$ (other source dependents), 92.24\% said that they do not use any type of purification method, such as boiling or adding chemicals to the water before them drink. Only 7.76\% (17) sample HHs (all from private meter connection) responded that they use purification method. Of these, $5.94 \%$ (13) of them use chemical called "wuha hagar", while $1.83 \%$ (4) of them use boiling mechanism for purification. They do this specially during the rainy season when the color of water gets red. Unfortunately as to the information obtained reveals, though 17 households use purification methods; they do not use it consistently. This indicates as the majorities do not use any purification method.

\subsubsection{Public / Consumer's Perceptions on Service Deliveries}

Regarding the level of the existing water supply and service delivery, out of the total sampled households, the majority $76.26 \%$ (167) said that it is poor and hence they showed, that they are dissatisfied with the status quo level, while $17.35 \%$ (38) replied that it is satisfactory, the rest $6.39 \%$ (14) responded that it is good.

Depending on the source of water used, the level of dissatisfaction of respondents shows difference between public and own tap users. The reason of dissatisfaction of own tap users is connected with unreliability of water services, inadequate quantity and also related with the existing tariff structure (see table 7). While the dissatisfaction of public tap users is connected to the inconveniency in time and the distribution of public tap, which was responded by $70 \%$ and $30 \%$ of households respectively.

Concerning willingness to pay for the current water supply service, out of the total surveyed households, $49.77 \%$ (109) respondents are willing to pay, while $45.21 \%$ (99) responded that they are not willing due to unaffordability of water tariff and unreliability of the service. The rest 5.02\% (11) HHs were unwilling to say any and hence, no response. This implies that the majority of Gimbi people are willing to pay due to the fact that water is crucial for their life, though majority claimed that the tariff is high.

\subsection{Factors for Inadequate Water Supply Infrastructure and Service Delivery}

As it was noted above, currently, water supply infrastructure and service delivery in Gimbi town is below the acceptable international standards. This situation is demonstrated in Gimbi; whereby the levels of coverage are low; the existing pipelines and reservoirs are insufficient and supply networks are also in a state of disrepair. The major factors responsible for these situations are the following:

Population Growth: As discussed under the background of the study area, rapid growth of population is observed in the town. This population increment demands large volumes of water supply. On the other hand, the existing water infrastructure could not allow the production of large quantities of water because the existing water supply source was designed to alleviate the problems of potable water prevailing in the town before 15 years ago. This scheme was designed without considering the future population growth in the town. The problem was exacerbated with the opening of the higher institutions and housing construction coupled with people who migrated to the town for education and other purposes. The existing consumption pattern aggravated the problem to accommodate the need of the steady growing population with the limited resources. This condition made the demand higher than the existing supply.

Intermittent Water Supply: As indicated in Table 3, one of the reasons for using unprotected sources of water is the frequent interruption of water supply service. It is one of the factors that limits smooth flow of water and causes water shortage, which is responsible for inadequate water supply service. According to Gimbi town WSSS office, the main causes of water supply interruptions are inadequacy of the existing source. The sampled HHs also responded to this as to their understanding and consequently, $42.92 \%$ cut off electric power, $47.03 \%$ breakdown of main pipelines during road construction and the remaining $10.05 \%$ related the situation with inefficiency of operation and maintenance department of the sector.

As the above obtained response shows, the utility office lacks competence to increase the capacity of the existing source and also take appropriate measures to tackle the prevailing problems. The interruption of water service in addition to creating inconveniency greatly reduces the amount of water consumption and devastate source of income of the sector.

Unaccounted-for Water: It is water produced, but failed to reach the final consumers due to various problems mainly related to distribution systems. High rate of water losses from the distribution systems and poor distribution efficiency through city networks are also the other contributing factors for the inadequate supply of water services. As it was observed in the study area, about $41.25 \%$ of water produced does not reach the customers (see Table 4).

This shows water loss has further reduced the amount of water supply that can reach the customers and is becoming an additional problem to water shortage and scarcity. It also reduces the revenue of the water supply service office, which might be used for the improvement of the physical infrastructure of the town water supply service.

Inadequate Water Source: The source of the town water supply is used for irrigation at its upstream, which 
reduces the quantity and quality of water by increasing turbidity in the raw water. Moreover, especially during the summer season, the raw water becomes full of wastes as it drains from the town through sheet erosion. Besides, there is dry coffee processing plants near and around the raw water or intake site. The waste particles from these plants clog the pipelines and also affect the quality of water. All these become additional work to purify the water, which in turn contributes to the interruption of service since time is taken to make the water potable.

Problems within the Treatment Plant: High content of turbidity and other wastes in the raw water are frequently clogging the filter. As a result, chemical coagulation system is manually incorporated and the roughing filter boxes are used as sedimentation tank, which is laborious work and time consuming to distribute treated water as the process involves long time. This in turn, becomes responsible for inadequate water supply service.

Distribution System: Rugged terrain of the town makes the extension of pipelines difficult and also distribution by gravity system is absolutely impossible. As it was stated, the pipeline network consist loop and branch system to store the water in the reservoir and distribute to the customers. In addition, due to low pressure the existing network lines cannot cover the customers at the same time. Thus, pumping distribution method needs energy to pump the water from the source to the treatment site and then to the consumers, which is energy consuming and increase loss. Lack of standby diesel generator, leak detection technology and insufficiency of networks are some of the other problems within the distribution system.

Inefficient Capacity: Shortage of skilled manpower particularly in O\&M is the critical issue faced by the WSSS office. This constraint is also the most limiting factor in the fulfillment of its service provision. In addition to this, inappropriate location of the office, insufficient vehicles, incompatible payment and lack of incentives; in short inadequate equipment facilities and other material resources further exacerbated the nature of the problem.

Insufficient Stakeholders' Participation: Common participation in the project identification, construction, O\&M of schemes is low. To check whether the customers themselves are collaborative, HHs were asked if they report when breakage occurs on their water supply system. Accordingly, 42.92\% (94) responded that they report, $48.89 \%$ (107) replied they do not and the remaining 8.22\% (18) have no response. The reason of the 107 respondents for not reporting to the WSSS office is the following. 57.01\% (61) lack of awareness about the effect of water loss through breakage, $36.49 \%$ (39) HHs responded the office is too far and the response of $20.56 \%$ (22) is lack of immediate response from the sector. This shows the majority do not report while breakage occurs on their water supply system, which indicates low participation from the stakeholders.

Inadequate Budget: Water sector development projects by their nature require high level of investment. Lack of sufficient funding has imposed limits on the quantity and quality of outputs and became an obstacle to expand the services and then increase access, which in turn increase the coverage. As it was discussed in the preceding topic, the revenue generated from water sales and meter rent are the main source of budget of the sector. Revenue is generated from these sources if the customers are willing to pay fees required from them. Lack of effective cost recovery mechanisms often inhabit the ability of institutions to sustain.

Lack of Appropriate Operation and Management: In water supply programs, one of the most serious problems is poor maintenance of systems once they have been built. Therefore, lack of regular rehabilitation is one of the chronic problems that have been continually upsetting the water sector and debilitating whatever meager efforts where put towards development. The causes are many among which include: improper designs, wrong technologies, use of expensive equipment, lack of spare parts, lack of trained manpower, lack of rehabilitation programs, and low level of community participation and lack of monitoring mechanisms.

Lack of Institutional Integration and Coordination: There is no integration and coordination between and among the town's basic urban infrastructure providers like Ethiopian Electric Power Corporation (EEPC), Ethiopian Telecom, and Road Authority and Water Resource Sector in Gimbi town. Even there is no integrated plan among the members of Gimbi town water board.

Inefficient and Inequitable Distribution of Water: The rate of meter connection and the spatial distribution of public standpipes do not meet the demands of the community. The distribution of public fountains did not take into consideration the number of people, density and distance between water points. The private meter connections for residential houses cover only $22.57 \%$. In short, the distribution system of private meter and public standpipe covers mainly the old settlement areas where pipelines are available.

\subsection{Socio-Economic Impacts of Inadequate Water Supply and Sanitation Services}

Sufficient potable water supply is one of the basic urban services, which highly affects the socio-economic progress of towns and the health of their people. Because of an inadequate and undesirable water supply: economic loss may result, manpower may be wasted, production of consumer goods and food may decline, fire protection may become impossible and schemes for urban improvement may fail. Many urban centers around the world including Gimbi town are facing serious problem resulting from lack of adequate water supply.

In case of Gimbi town, the existing source of water supply was found to be inadequate, which cannot meet 
the demand of the customers. Limited sources coupled with large volumes of loss, inequitable distribution system and low quality aggravated water problem in the town. In the town, the problem of water supply is not only adequacy and quality but also it has the problem of distribution and reliability, which influence the wellbeing of people in general and the socio-economic condition of the study area in particular:

Impact on Economic Development: As it is indicated in the previous discussion, water is delivered on an intermittent basis and also when supplied it is inadequate, which was witnessed by the majority of the surveyed households. As a result, almost all HHs collect their water from multiple sources including river and stream by traveling long distances. This shows how lack of access to safe water source exposes the HHs to unnecessary expenses that could have been devoted to other economic development activities. Due to lack of access to adequate water supply service, HHs were requested to mention problems they face, which is indicated in figure 4 . Figure 4: Problems HHs Face in Lack of Access to Water Supply Service in Gimbi Town

\section{Problems Households Encounter in Lack of Access to Safe Water Supply Service}

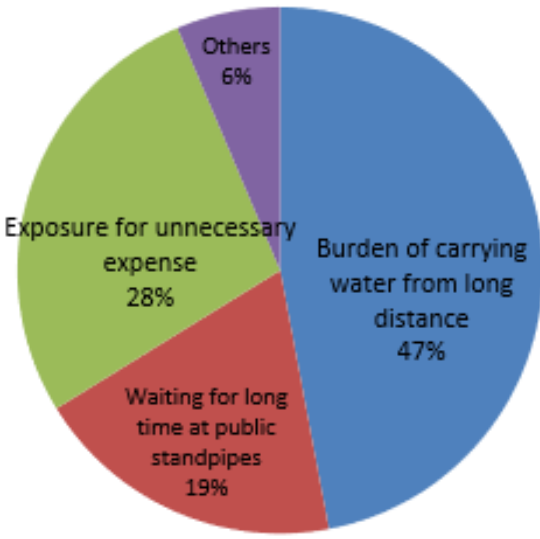

Source: Field Survey, 2016

As shown in Figure 4, it is evident that the problems the HHs encounter in lack of access to water supply service is burden of carrying water from long distance as replied by $47 \%$ of sample households, $28 \%$ said exposure for unnecessary expense, and waiting for long time at public standpipes are $19 \%$, while the mixtures of the above cases are $6 \%$. The other direct impact of inadequate water supply service on economic activities in the surveyed area in addition to domestic uses is on construction works, on service providers like hotels, local laundries, cafes and other local drink providers. Unfortunately, at the time when observation was made vis-à-vis the existing condition of water supply service of the town, many contractors were interrupting their works due to lack of water supply service. The same is true for others like hotels and restaurants. This indicates they are exposed to unnecessary expense, which affects their economic development.

Effect on Gender Equality: Households were asked about who is responsible to collect water and responses regarding this indicated that $81.74 \%$ (179) of the respondents said it is only female members of the family who are responsible to fetch water from outside source, $9.59 \%$ (21) of the respondents said male is responsible, whereas only $6.85 \%$ (15) said it is the duty of either female or male, there is no sex differentiation and the rest $1.83 \%$ (4) said they use daily laborers whenever they want to bring water. Majority of the respondents confirmed responsibility of fetching water from outside source is female member of the family.

Response from the sampled HHs regarding the more affected group as a result of lack of access to adequate water supply service indicated that $53.88 \%$ (118) women, $32.88 \%$ (72) children and the rest, $16.44 \%$ (36) gave both children and women. This shows women are the most affected followed by children from burden of carrying water from long distance and waiting for long time at the sources eventually resulting in tiredness and fatigue. In addition, queuing at water points also creates disputes among those waiting in a line when queue jumping occurs. In short, as they commit large shares of their time in obtaining water, they loss economy, which could otherwise be devoted to other important activities, especially school aged children.

Effect on the Health Due to Lack of Access to Water Supply Service: Inability to get adequate safe water means poor health and low productivity of the society, due to absent from work by losing working days, which in turn reduce GDP. This leads to low national income, poverty and then low living standard of the society. This calls for the provision of adequate potable water, which improves health by reducing incidence of water related illnesses.

In Gimbi town, as information obtained in the preceding discussion showed, large proportions of HHs use water what nature has provided them, which are often unsafe, and cause health hazards. To examine this, all sample households were asked whether there is anyone of the family member who has ever been sick by water- 
borne disease. Accordingly, 20.8 percent said there is diarrhea, 29.2\% respond at least one family member was sick by typhoid, $24.34 \%$ respond at least one family member was sick by typhus and $15.04 \%$ responded that the disease is both typhoid and typhus. The rest $10.62 \%$ responded that there is disease manifested for which they cannot state the name.

To confirm the truth, whether the frequent occurrences of diseases in the town have related to water-borne, and the researcher contacted Gimbi Town Health Center. Consequently, as the report from the sector in 2016 illustrates water-borne diseases were one of the ten top diseases in the town in which typhoid and typhus, diarrhea, and intestinal parasite are included. Overall, safe drinking water is of crucial importance to the preservation of human health, especially among children and women.

\subsection{Conclusion}

It is widely recognized that the presence of adequate safe water supply and service delivery is one of the basic requirements of human beings. In connection with the existing condition of the water supply infrastructure and service delivery of Gimbi town, information was obtained from primary and secondary sources. Accordingly, as the information reveals, the majorities of the town's populations collect potable water from the piped source. However, there are still large population numbers that utilize mixed sources and there are also non-pipe water users, which cannot be found within a reasonable distance and quantity. This is because the water supply of the town is inadequate to satisfy the needs of the inhabitants due to; limited source, frequent interruption, high water loss accounting to $41.25 \%$, limited number of reservoirs and low capacity, limited number of public fountains and their unfair distribution coupled with high demand of water for various purposes resulting from rapid population growth. All these together exacerbated the problem of the town water supply. Due to this, majority of the customers were not satisfied with the service provided by the utility.

Thus, the existing water supply of the town does not meet the current demand of the town population. The average daily water supply of the town is only $352.5 \mathrm{M}^{3}$, which can be 6.08 liters per person per day. Therefore, to provide the town populations with adequate water supply as to MoWR standard, additional $807.5 \mathrm{M}^{3}$ supplies are daily required to meet the domestic demand of the residents. Furthermore, as the supply and demand situation of the town reveals, the average coverage of the town water supply is $30.39 \%$ of the total demand of water supply of the town, which is for domestic use only, showing low coverage of service in Gimbi town. There is also limited number of public fountains and low access to water supply in the town.

Despite private meter connection is taken as best standard of water supply service; the rate of meter connection is low, which is $22.57 \%$ for residential customers implying inefficient distribution system. As stated in the analysis phase, low level of income of the households, high charge of installation, high tariff for private tap, limited network coverage, rugged topography of the town and lack of town houses were factors hindering meter connection. Consequently, the majorities of the residents are public fountain users, which is deficient. Therefore, household water consumption $(1 / \mathrm{c} / \mathrm{d})$ is higher for public fountain users than other source users. Whereas, that of own pipe users is more than public fountain users. In addition, family size and income level of the households were found to be the other factors determining household's water consumption in Gimbi town.

Institutional framework and organizational capacity related issues are the other concern assessed in this study to provide efficient and effective service delivery. Accordingly, low capacity of the institution is one reason for water supply service inadequacy. The capacity of the institution is reduced by a number of factors, including shortage of funds, poor performance, and lack of coordination. Lack of technical manpower capacity is critical problem as stated in the analysis phase as most of the employees in the office were under the expected qualification and also their profession is not related to the job they are working. This aggravated the problem of O\&M and other managing systems and increased the problem of water loss. Other problems are lack of stakeholders' participation in planning and operation of water supply infrastructure as well as lack of proper equipment and finance and cost recovery.

In consequence of the inefficiency of water supply of the town, the majorities of the inhabitants collect water from other sources, which are unprotected and vulnerable to health hazards. Some customers also supplement their water by buying from water vendors and paying relatively high prices for it. In addition to the inadequate nature of the source, frequent interruption occurs constantly, which exacerbated water shortage. As a result, the customers are forced to use multi sources fetching from longer distances, which exposes the households to unnecessary expense in terms of time, energy and Labour. It was identified from the analysis that female groups of the community followed by children are responsible to collect water from unreasonable distances being exposed to various problems such as physical, social and mental problems.

\subsection{Recommendations}

The discussion and findings in the preceding sections provide some highlights into avenues for future research. In order to improve Water Supply Infrastructure and Service Delivery in terms of quality, quantity, reliability and sustainability, which in turn improve the socio-economic welfare of the inhabitants, the following measures 
need to be taken: Exploring additional source of water, carrying out appropriate operation and maintenance, equitable distribution, strengthen the institutional capacity, encouraging stakeholders' participation, appropriate management of water infrastructural assets, harmonization of pipe water and other sources, using water reservoirs, introducing water harvesting program and using alternative power.

\section{References}

Aid, W. (2006). Bridging the Gap: Citizens' Action for Accountability in Water and Sanitation. Water Aid.

Arlosoroff, S. (1999, June). Water Demand Management. In International Symposium on Efficient Water use in Urban Areas, IECT-WHO, Kobe, Japan.

Assefa Delesho (2006). Urban Water Supply: the Case of Assosa Town. MA. Thesis, Addis Ababa University, Ethiopia.

Bissoon, O. (2011). Can Better Institutions Attract More Foreign Direct Investment (FDI)? Evidence from Developing Countries. In International Conference on Applied Economics (pp. 59-70).

Buchberger, S. G., \& Nadimpalli, G. (2004). Leak Estimation in Water Distribution Systems by Statistical Analysis of Flow Readings. Journal of Water Resources Planning and Management, 130(4), 321-329.

Devarajan, S., \& Reinikka, R. (2003). Making Services Work for Poor People. World Bank and Oxford University Press.

Habitat UN, (2006). The State of the World's Cities Report 2006/2007. The Millennium Development Goals and Urban Sustainability, 30.

Hoebink, P., Schulpen, L., House, P., \& Place, S. (1998). Netherlands Aid Policies for Poverty Reduction. London: Overseas Development Institute

Khatri, K. B., \& Vairavamoorthy, K. (2007). Challenges for Urban Water Supply and Sanitation in the Developing Countries, Discussion Draft Paper.

Ladele, A. A., \& Tackie-Ofosu, V. (2013). Gender Analysis of Commitment and Participation in Rural Water Supply Project in Suhum Kraboa Coaltar District of the Eastern Region of Ghana. Journal of Sustainable Development in Africa, 15(4), 86-98.

Larry, M., ed., (2004). Water Supply Systems Security, Department of Civil and Environment Engineering, in: Tempe, eds-in-chief, Arizona State University, USA.

Le Gouais, A., \& Wach, E. (2013). A Qualitative Analysis of Rural Water Sector Policy Documents. Water Alternatives, 6(3), 439-461.

MoWR (2001). Ethiopian Water Sector Strategy. Addis Ababa., Ethiopia.

MUWD (2006). Industry and Urban Development Package (Unpublished). Addis Ababa, Ethiopia.

UN Centre for Human Settlements (Habitat). UN Centre for Human Settlements (Habitat). (1996). An Urbanizing World: Global Report on Human Settlements 1996. Oxford University Press.

UNEP (2002). Global Environment Outlook 3, www. savewater.com.au

UN (2004). The African Water Vision for 2025: Equitable and Sustainable use of Water for Socio Economic Development. Economic Commission for Africa, Addis Ababa.

WSSS Office (2016). Organizational structure of Gimbi Town WSSS Office.

WSSS Office (2016). Existing Tariff of Gimbi Town Water Supply Service

West Wollega Zone (2008). West Wollega Zone Finance and Economic Development Office

World Health Organization. (1994). Operation and Maintenance of Urban Water Supply and Sanitation Systems. Geneva, Switzerland: Author.

World Health Organization. (2000). Global Water Supply and Sanitation Assessment 2000 Report. World Health Organization.

World Health Organization (WHO, \& UNICEF. (2000). Global Water Supply and Sanitation Assessment 2000 Report. World Health Organization (WHO).

Water, S., \& World Health Organization. (2004). Meeting the MDG Drinking Water and Sanitation Target: a Mid-Term Assessment of Progress.

Yamamura, S., Bartram, J., Csanady, M., Gorchev, H. G., \& Redekopp, A. (2003). Drinking Water Guidelines and Standards. Arsenic, Water, and Health: the State of the Art. Geneva: World Health Organization.

Zetland, D., \& Gasson, C. (2013). A Global Survey of Urban Water Tariffs: are they Sustainable, Efficient and Fair? International Journal of Water Resources Development, 29(3), 327-342. 
